\title{
Responses of Fig Cuttings (Ficus carica) to Different Sowing Dates and Potting Media under Agro-Climatic Conditions of Haripur
}

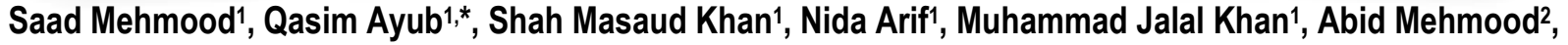
Qammer Shahzad ${ }^{3}$, Naveed ul Haq ${ }^{3}$, Muhammad Tehseen Zaheer Tanoli4, Muhammad Umer Ayub

${ }^{1}$ Department of Horticulture, University of Haripur, KPK, Pakistan.

2Department of Agronomy, University of Haripur, KPK, Pakistan.

3Department of Food Science and Technology, University of Haripur, KPK, Pakistan.

${ }^{4}$ Department of Plant Breeding and Genetics, University of Haripur, KPK, Pakistan.

\section{ABSTRACT}

Background: Fig belongs to tropical and subtropical climates, and Haripur district being a subtropical area have great potential for successful commercial cultivation of figs. The most common method of fig propagation is by hardwood cutting, which is an easy and economical way of propagation. But lack of knowledge regarding suitable date of cutting collection and sowing and selection of appropriate potting medium severely limits the production of fig on a commercial scale.

Objectives: Current study was undertaken in order to identify suitable collecting dates of fig cuttings and to develop a suitable potting media for the successful establishment of fig cutting.

Methodology: The study was comprised of four different potting media i.e. soil, farmyard or manure (FYM), compost, Soil+FYM+Compost (1:1:1) and cuttings of fig cultivar Sawari were collected and sown on two different dates i.e. $1^{\text {st }}$ January and $15^{\text {th }}$ January in polyethene bags of uniform size. The experiment was laid in Complete Randomized Design (CRD).

Results: Results revealed that maximum length of the root $(9.8 \mathrm{~cm})$, shoot thickness $(1.4 \mathrm{~cm})$ and number of leaves $(4.1)$ were noted in FYM, whereas maximum days to sprouting (18.5) and survival percentage (82.3\%) were noted in Soil+FYM+Compost (1:1:1). Whereas fig cutting sown on $15^{\text {th }}$ January showed maximum days to sprouting $(18.8)$, length of the root $(9.4 \mathrm{~cm})$, survival percentage $(87.1 \%)$, shoot thickness $(1.8 \mathrm{~cm})$ and number of leaves (4.6).

Conclusion: It can be concluded that FYM and $15^{\text {th }}$ January showed highest values of studied parameters.

\begin{tabular}{|c|c|c|}
\hline Keywords & *Address of Correspondence & Article info. \\
\hline $\begin{array}{l}\text { Asexual Propagation, Collection Dates, } \\
\text { Cutting, Fig, Haripur, Media. }\end{array}$ & qasimayub.alizai@gmail.com & $\begin{array}{l}\text { Received: January 14, } 2020 \\
\text { Accepted: October 15, } 2020\end{array}$ \\
\hline
\end{tabular}

Cite this article: Mehmood S, Ayub Q, Khan SM, Arif N, Khan MJ, Mehmood A, Shahzad Q, Haq

$N$, Tanoli MTZ, Ayub MU. Responses of Fig Cuttings (Ficus Carica) to Different Sowing Dates and Potting Media under Agro-Climatic Conditions of Haripur. RADS J Biol Res Appl Sci. 2020;

11(2):112-119.

This is an Open Access article distributed under the terms of the Creative Commons Attribution License (http://creativecommons.org/licenses/by/4.0), which permits unrestricted use, distribution, and reproduction in any medium provided the original work is properly cited.

\section{INTRODUCTION}

Fig (Ficus carica L.) is an important member of Moraceae family. The genus consists of almost 900 species in the world, which are believed to be originated in cold and temperate tropical regions like those of Middle East,
Turkey, Africa and India ${ }^{1}$. Genus Ficus is of higher important genetic resource because of its high nutritional and economic values and is also a vital part of the biodiversity in the rainforest. Ficus also serve as a 
sustainable food source to fruit loving animals in tropical and subtropical forests. Now, fig fruit is being cultivated extensively in many regions of the world because of its higher adaptability in variable climatic and soil types and shows minimum signs of deficiencies or any toxicity symptoms ${ }^{2}$. Fig trees can be grown successfully up to an altitude of 1,525 $\mathrm{m}$ above sea level and require a warmer summer accompanied with mild winter, but it can be cultivated under fever favorable conditions ${ }^{3}$. The tropical and subtropical regions are also suitable for fig cultivation if proper irrigation is carried out when required. Fig can tolerate low temperatures up to $10^{\circ} \mathrm{C}$ and are forest hardy, but in case of severe frost, the top growth of the tree can be damaged and under harsh winter conditions tree can be killed back to the base. At higher altitudes, fig show deciduous behavior but do not need any amount of winter chilling to break the dormancy; but at lower altitude it can grow throughout the year4.

The importance of the fig is more evident by the fact that it is mentioned in the Holy Quran in Sura At Tin, which narrates "[l swear] by the fig and the olive." the mention of fig in Quran clearly represents its importance and indicates the benefits of fig consumption (Anonymous $2017)^{5}$. Along with the Quranic verse Prophet Muhammad (PBUH) also described the importance of fig consumption in a Hadith which narrates that "Eat figs! If I would say a certain type of fruit was sent down to us from the heaven I would say fig because it has no seeds. It ends the piles and is useful for rheumatism." (by Abu Darda). Hence, Islam also recommends the consumption of fig fruit in daily diet 6 .

Fig has got the attention of consumers throughout the world due to its nutritional and medicinal values and considered as one of the healthiest components of the diet and is associated with long life ${ }^{7}$. It is a good source of many vitamins, vital minerals, dietary fiber, and some polyphenols with no fats and cholesterol and has rich contents of antioxidants 8 . Various parts of the plant like bark, leaves, tender shoots, fruits, seeds, and latex have medicinal impertinence. The fig is a very nourishing food and used in industrial products 9 .

Fig nursery plants production is mainly based on cuttings taken from the mother tree and placed in a rooting media, which will eventually produce roots and new shoots ${ }^{10}$. The traditional method for growing fig consisted of taking cuttings from one or two-year-old shoots and directly planting them in media to obtain new trees ${ }^{11}$. Under the recent marketing situation of fresh figs, the experiments were carried out to improve the propagation of figs by hardwood cuttings. The success in stem cutting multiplication of fruits crops depend upon many crucial factors like the condition of the mother plant, part of the tree, age of the tree from where cuttings are taken, the condition of the part of the tree from where the cuttings are made, time of planting and rooting media. Some factors that affect the rooting of fig cuttings are season and time of cutting, rooting medium, physiological condition of the mother plant, type of cuttings, and use of rooting hormones ${ }^{12}$.

Suitable plant media have marked influence on plant's health. A media which is rich in nutrients, well absorbent of water and properly drained is considered at perfect for plant growth and development. A higher yield of the best quality plant is entirely based on physico-chemical characteristics of growing substrates. Good media have beneficial effects on plants due to the superior retention of water and cation exchange ability. Potting media provides basic needs of plant through its growth. The physical and chemical characteristics of potting media help plants in better development of roots and proper nourishment of plants ${ }^{13}$.

Farmers and nurserymen have been using different propagation methods to produce healthy and vigorous trees by using different potting media. Many investigations have been conducted to identify suitable time of collection and sowing of fig cutting along with suitable growing media for propagation of fig but no proper work has been done at Haripur region to investigate the responses of different collecting dates and potting media on the growth of fig. The identification of suitable potting media and sowing dates of cutting will help to develop fig sector, hence, this study was undertaken to select potting media for fig cutting and to select suitable collecting dates for fig sowing.

\section{MATERIAL AND METHODS}

Site Description: Pot experiment was conducted to investigate the "Responses of fig cuttings to different sowing dates and potting media" at Horticulture Nursery, The University of Haripur during January to April 2019. 
The Horticulture Nursery has situated in district Haripur with $33^{\circ} 44^{\prime} \mathrm{N}$ latitude, $72^{\circ} 35^{\prime} \mathrm{E}$ longitude and altitude of $610 \mathrm{~m}$ from the mean sea level. The overall mean temperature and rainfall during the experimental period are given in (Fig. 1).

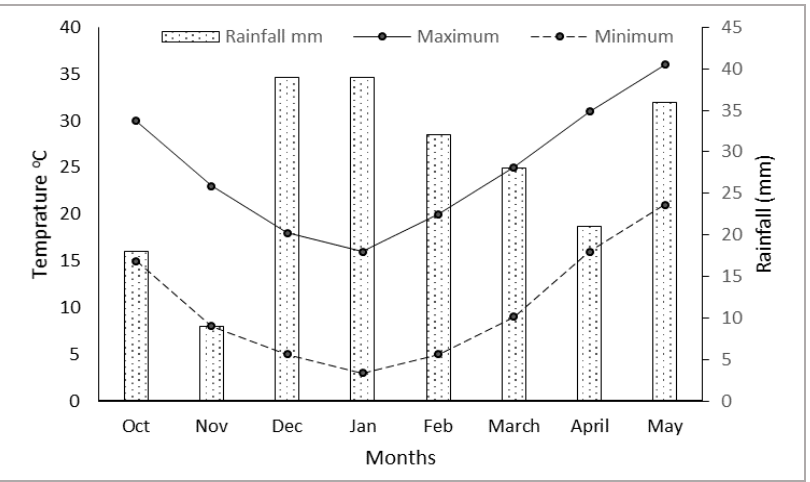

Fig 1. Average weather condition during the experiment period.

Media and Pot Preparation: For this experiment, four different potting media were used, which includes garden soil, farmyard manure (FYM), compost and mixed media (Soil+Compost+FYM @ 1:1:1). The compost was collected from Department of Soil Science, University of Haripur, which is made up of food wastes of university canteen, dead and fallen parts of plant planted in the premises of the campus and the grasses of the lawn. Whereas, mixed media was prepared by mixing an equal amount of soil, FYM and compost. These potting media were then filled in earthen pots (14 inches in diameter). The complete chemical profile of each media is given below (Appendix-1).

Cutting Collection: Cutting of fig cultivar Sawari was collected from Tarnab Farm, Peshawar, where $30 \mathrm{~cm}$ long fig cutting with uniform thickness were collected from healthy mother plant. One cutting per pot was planted and each pot was considered as a single replication.
Sowing of Cuttings: Fig cuttings were collected and sown on two different dates i.e. on $1^{\text {st }}$ January and on $15^{\text {th }}$ January. Cuttings were sown in pots which were properly filled by media and then kept at a plastic tunnel. All cultural practices like weeding, hoeing, irrigation were carried evenly throughout the study period.

Experimental Design and Statistical Analysis: Experiment was laid out in Complete Randomized Design (CRD) with two factors i.e. potting media and sowing dates. Each treatment (potting media) was replicated three times. The data collected on different parameters was subjected to analysis of variance (ANOVA) technique to observe the difference, between different treatments as well as their interactions. In a case where the difference was significant the mean was further assessed for differences through the Least Significant Difference (LSD) test at $p=0.05$. Statistical computer software (Statistics 8.1) was applied for computing both ANOVA and LSD ${ }^{14}$.

Parameters: Data regarding days to sprouting, length of the root $(\mathrm{cm})$, survival percentage $(\mathrm{cm})$, shoot thickness $(\mathrm{cm})$ and number of leaves/plants were recorded during the experiment. A total number of days to sprouting was calculated by counting the days taken by each cutting of fig to sprout. Length of the root was measured from base to the tip of longest root with the help of ruler. Survival percentage was calculated by using the following formula:

$$
\text { Survival } \%=\frac{\text { Number of sprouted cuttings }}{\text { Total number of cuttings sown }} \times 100
$$

Shoot thickness was determined by measuring the thickness of cuttings 1 inch above the soil line by using vernier's caliper. The total number of leaves in sprouted cutting was counted and means were calculated.

Appendix-1. Physico-Chemical Properties of Different Potting Media.

\begin{tabular}{ccccccc}
\hline S. No. & Media & Porosity (\%) & Water Holding Capacity (\%) & N (ppm) & P (ppm) & K(ppm) \\
\hline 1 & FYM & 95 & 74 & 0.126 & 6.32 & 74 \\
\hline 2 & Compost & 91 & 64 & 0.099 & 5.89 & 63 \\
\hline 3 & Soil & 79 & 36 & 0.064 & 3.42 & 43 \\
\hline 4 & Mixed Media & 85 & 53 & 0.087 & 4.60 & 56 \\
\hline
\end{tabular}




\section{RESULTS}

\section{Days to Sprouting}

Analysis of variance showed that highly significant difference was observed regarding potting media, date and interaction of potting media and dates (Table 1). Maximum days to sprouting (18.5) were observed in mixture of FYM+Soil+Compost closely followed by soil (18.1), whereas minimum days to sprouting (15) in FYM. Likewise, maximum days to sprouting (18.8) were noted in cuttings which were sown on $15^{\text {th }}$ January, whereas minimum days taken for sprouting (15.5) were noted in cutting sown at 1 st January. The interaction of date and potting media reveled that maximum days to sprouting (20.6) were noted in those cutting which were sown on $1^{\text {st }}$ January and planted in soil, whereas minimum days to sprouting (13.6) were observed in $15^{\text {th }}$ January and FYM. These results are in agreement with the findings of Antunes et al., (2001) $)^{10}$.

\section{Length of Root $(\mathrm{cm})$}

Data regarding length of root showed that significant variations were observed regarding potting media, date and interaction of potting media (Table 2). Maximum length of the root $(9.8 \mathrm{~cm})$ was observed in FYM followed by $(8.0 \mathrm{~cm})$ in compost, whereas, minimum root length $(6$ $\mathrm{cm})$ in soil. Similarly, maximum length of roots $(9.4 \mathrm{~cm})$ was noted in those cuttings which were sown on $15^{\text {th }}$ January whereas minimum root length $(6.5 \mathrm{~cm})$ was noted in cutting sown at $1^{\text {st }}$ January. The interaction of date and treatments reveled that maximum root length $(11.6 \mathrm{~cm})$ was noted in those cutting which were sown on $15^{\text {th }}$ January and planted in FYM whereas minimum length of roots $(4.3 \mathrm{~cm})$ were observed on 1 st January in soil. Similar findings have been previously reported by Ozenc, $(2007)^{15}$ in kiwifruit.

Table 1. Effect of Potting Media and Sowing Dates on Days to Sprouting of Fig Cutting.

\begin{tabular}{ccccc}
\hline \multirow{2}{*}{ S. No. } & Potting Media & \multicolumn{2}{c}{ Sowing Dates } & \multirow{2}{*}{ Means } \\
\cline { 3 - 4 } & M1 & $20.66 \mathrm{~A}$ & $15.66 \mathrm{E}$ & $18.16 \mathrm{~A}$ \\
\hline 1 & $\mathrm{M} 2$ & $16.33 \mathrm{DE}$ & $13.66 \mathrm{~F}$ & $15.00 \mathrm{C}$ \\
\hline 2 & $\mathrm{M} 3$ & $18.66 \mathrm{BC}$ & $15.33 \mathrm{E}$ & $17.00 \mathrm{~B}$ \\
\hline 3 & $\mathrm{M} 4$ & $19.66 \mathrm{AB}$ & $17.33 \mathrm{CD}$ & $18.50 \mathrm{~A}$ \\
\hline 5 & Means & $18.83 \mathrm{~A}$ & $15.50 \mathrm{~B}$ & \\
\hline
\end{tabular}

$M 1=$ Soil, M2= FYM, M3=Compost, M4= Soil+FYM+Compost (1:1:1), D1=1st January, $D 2=15^{\text {th }}$ January.

Table 2. Effect of Potting Media and Sowing Dates on Length of Root $(\mathrm{cm})$ of Fig Cutting.

\begin{tabular}{ccccc}
\hline \multirow{2}{*}{ S. No. } & Potting Media & \multicolumn{2}{c}{ Sowing Dates } & \multirow{2}{*}{ Means } \\
\cline { 2 - 4 } & & D1 & D2 & \\
\hline 1 & M1 & $4.33 \mathrm{~F}$ & $8.00 \mathrm{CD}$ & $6.00 \mathrm{C}$ \\
\hline 2 & $\mathrm{M} 2$ & $8.00 \mathrm{CD}$ & $11.66 \mathrm{~A}$ & $9.83 \mathrm{~A}$ \\
\hline 3 & $\mathrm{M} 3$ & $6.33 \mathrm{E}$ & $9.66 \mathrm{~B}$ & $8.00 \mathrm{~B}$ \\
\hline 4 & $\mathrm{M} 4$ & $7.33 \mathrm{DE}$ & $8.66 \mathrm{BC}$ & $8.00 \mathrm{~B}$ \\
\hline 5 & Means & $6.50 \mathrm{~B}$ & $9.41 \mathrm{~A}$ & \\
\hline
\end{tabular}

$M 1=$ Soil, M2= FYM, M3=Compost, M4= Soil+FYM+Compost (1:1:1), D1=1st January, $D 2=15^{\text {th }}$ January. 


\section{Survival Percentage (\%)}

Results relating to survival percentage (\%) showed that the highest survival percentage (82.3\%) was observed in a mixture of Soil+FYM+Compost, whereas minimum survival percentage $(70.6 \%)$ was recorded in soil (Table 3). Maximum survival (87.1\%) was noted in those cuttings which were sown on $15^{\text {th }}$ January whereas least survival percent $(70.0 \%)$ were observed in fig cuttings which were sown on $1^{\text {st }}$ January. The interaction of date and potting media reveled that maximum Survival percentage $(92 \%)$ were noted in those cutting which were sown on 15 January and planted in FYM whereas minimum Survival percentage $(60 \%)$ were observed in cutting which was sown on $1^{\text {st }}$ January in soil. Similar findings were also supported by Pirlak, (2000)16 in Cornelian cherry (Cornus mas L.). The findings of our experiments are also in accordance with those of Hussain et al., (2018) ${ }^{17}$.

\section{Shoot Thickness (cm)}

Analysis of variance showed that highly significant differences were observed regarding potting media, dates and interaction of potting media and dates for shoot thickness (Table 4). Maximum shoot thickness $(1.4 \mathrm{~cm})$ was observed in FYM whereas minimum shoot thickness $(1.2 \mathrm{~cm})$ was obtained in cutting planted in soil. Maximum shoot thickness $(1.8 \mathrm{~cm})$ was noted in those cuttings which were sown on $15^{\text {th }}$ January while least values of shoot thickness $(0.79 \mathrm{~cm})$ was observed in cutting which were sown on $1^{\text {st }}$ January. The interaction of sowing date and potting media reveled that highest shoot thickness $(2.1 \mathrm{~cm})$ was noted in those cutting which were sown on $15^{\text {th }}$ January and planted in FYM whereas minimum shoot thickness $(0.7 \mathrm{~cm})$ was observed on $1^{\text {st }}$ January and in compost. Hussain et al., (2018) $)^{17}$ also obtained the similar results.

Table 3. Effect of Potting Media and Sowing Dates on Survival Percentage (\%) of Fig Cutting.

\begin{tabular}{ccccc}
\hline \multirow{2}{*}{ S. No. } & Potting Media & \multicolumn{2}{c}{ Sowing Dates } & \multirow{2}{*}{ Means } \\
\cline { 3 - 4 } & M1 & D1 & D2 & \\
\hline 1 & M2 & $60.0 \mathrm{G}$ & $81.3 \mathrm{D}$ & $70.6 \mathrm{C}$ \\
\hline 2 & M3 & $72.3 \mathrm{~F}$ & $92.0 \mathrm{~A}$ & $82.1 \mathrm{~A}$ \\
\hline 3 & M4 & $73.6 \mathrm{~F}$ & $86.3 \mathrm{C}$ & $80.0 \mathrm{~B}$ \\
\hline 4 & Means & $75.6 \mathrm{E}$ & $89.0 \mathrm{~B}$ & $82.3 \mathrm{~A}$ \\
\hline 5 & $70.4 \mathrm{~B}$ & $87.1 \mathrm{~A}$ & \\
\hline
\end{tabular}

$M 1=$ Soil, M2= FYM, M3=Compost, M4= Soil+FYM+Compost (1:1:1), D1=1st January, D2=15 th January.

Table 4. Effect of Potting Media and Sowing Dates on Shoot Thickness $(\mathrm{cm})$ of Fig Cutting.

\begin{tabular}{ccccc}
\hline \multirow{2}{*}{ S. No. } & Potting Media & \multicolumn{2}{c}{ Sowing Dates } & \multirow{2}{*}{ Means } \\
\cline { 3 - 4 } & M1 & D1 & D2 & \\
\hline 1 & M2 & $0.86 \mathrm{D}$ & $1.60 \mathrm{C}$ & $1.23 \mathrm{C}$ \\
\hline 2 & $\mathrm{M} 3$ & $0.80 \mathrm{DE}$ & $2.10 \mathrm{~A}$ & $1.45 \mathrm{~A}$ \\
\hline 3 & $\mathrm{M} 4$ & $0.80 \mathrm{DE}$ & $1.90 \mathrm{~B}$ & $1.35 \mathrm{AB}$ \\
\hline 4 & Means & $0.70 \mathrm{E}$ & $1.93 \mathrm{~B}$ & $1.31 \mathrm{BC}$ \\
\hline 5 & $0.79 \mathrm{~B}$ & $1.88 \mathrm{~A}$ & \\
\hline
\end{tabular}

$M 1=$ Soil, M2= FYM, M3=Compost, M4= Soil+FYM+Compost (1:1:1), D1=1st January, $D 2=15^{\text {th }}$ January. 
Table 5. Effect of Potting Media and Sowing Dates on Number of Leaves per Plant of Fig Cutting.

\begin{tabular}{ccccc}
\hline \multirow{2}{*}{ S. No. } & Potting Media & \multicolumn{2}{c}{ Sowing Dates } & \multirow{2}{*}{ Means } \\
\cline { 2 - 4 } & M1 & D1 & D2 & \\
\hline 1 & M2 & $2.33 \mathrm{~B}$ & $3.3 \mathrm{~B}$ & $2.83 \mathrm{~B}$ \\
\hline 2 & M3 & $2.67 \mathrm{~B}$ & $5.67 \mathrm{~A}$ & $4.16 \mathrm{~A}$ \\
\hline 3 & M4 & $3.33 \mathrm{~B}$ & $5.00 \mathrm{~A}$ & $4.16 \mathrm{~A}$ \\
\hline 4 & Means & $2.33 \mathrm{~B}$ & $4.67 \mathrm{~A}$ & $3.50 \mathrm{AB}$ \\
\hline 5 & $2.67 \mathrm{~B}$ & $4.67 \mathrm{~A}$ & \\
\hline
\end{tabular}

$M 1=$ Soil, $M 2=F Y M, M 3=$ Compost, $M 4=$ Soil $+F Y M+$ Compost $(1: 1: 1), D 1=1$ st January, $D 2=15^{\text {th }}$ January.

\section{Number of Leaves per Plant}

Analysis of variance showed that highly significant differences were observed regarding potting media, dates and interaction of potting media (Table 5). Maximum number of leaves (4.1) was observed in both FYM and in compost, whereas minimum number of leaves (2.8) was recorded in soil. Results regarding sowing dates of fig cutting showed that greater number of leaves (4.6) was noted in those cuttings sown on $15^{\text {th }}$ January, whereas least number of leaves (2.6) was observed in cutting sown on $1^{\text {st }}$ January. The interaction of date and potting media reveled that highest number of leaves (5.6) was noted in those cutting which were sown on $15^{\text {th }}$ January and planted in FYM whereas minimum number of leaves (2.3) was observed in mixture of Soil+FYM+Compost and Soil. The interaction of dates and treatments for a number of leaves per plant is similar to Aljane ${ }^{11}$ and to Khan et al. $(2006)^{18}$.

\section{DISCUSSION}

Our results indicate that those cuttings which were planted in FYM are first to emerge among other cuttings, this may be attributed to high porosity, higher availability of moisture and nutrient to the cutting in FYM which in return enhances the physiological activity of fig cuttings and results in the early emergence of leaves in comparison to other potting media ${ }^{19}$. It was also observed that cutting which was sown on $1^{\text {st }}$ January experienced the lowest atmospheric temperature as compared to those cuttings which were sown to 15 January. This difference in temperature between the collecting dates is of prime importance to improve sprouting capacity.
Hartmann et al. (1997) ${ }^{20}$ stated that for most species, daytime temperatures between 21 and $27^{\circ} \mathrm{C}$ and a nighttime temperature of $15^{\circ} \mathrm{C}$, are satisfactory for fig rooting. On the other hand, the same researchers indicated that there has to be a support for the cuttings to improve multiplication and differentiation of buds.

Increase in root length be attribute to the nutritionally better mixture, high water and nutrient holding capacity, and high porosity of the media combination helped in the development of excellent rooting system and provided better conditions for free growth of roots. The increase in the length of the roots might be due to the presence of higher amounts of food reserves in cuttings sown at $1^{\text {st }}$ January which in turn supported better root growth and hence, increased its root length ${ }^{21}$.

High carbohydrate concentrations and low nitrogen levels of potting media are the key player in determining the survival of tree cutting. These chemicals have been reported to favor root formation, bud initiation and leaf development in shoots which increase the chances of cutting to sprout ${ }^{19}$. Shoot thickness mainly depends upon stored food inside stem and biomass. An increased stem thickness indicates the presence of biomass and the nutritional level of the media. Media having higher levels of nutrients and water holding capacity ensures the proper availability of nutrient and water at any time hence causes an increase in shoot thickness ${ }^{22}$.

The increase in number of leaves per cutting might be due to the reason that the plant might diverted maximum assimilate quantities to the leaf bud since the leaves are one of the production sites of natural auxins in them besides being very important for vital processes like 
photosynthesis and respiration. This could be attributed to the favorable temperature range $\left(27.9 / 15^{\circ} \mathrm{C}\right)$ available during the vegetative growth phase of this planting date. While the wider temperature range $\left(30.7 / 12^{\circ} \mathrm{C}\right)$ during the vegetative phase of planting date of $15^{\text {th }}$ January might have resulted in the reduction of a number of leaves per plant ${ }^{18}$.

\section{CONCLUSION}

From this study, it was concluded that fig cuttings which were sown on $15^{\text {th }}$ January have showed more promising result instead of those which were sown on 1 st January. Among different potting media mixture Compost and FYM have increased the different studies parameters. Therefore, from the above. study, it can be concluded that:

- Media and dates of stem sowing play an important role in production of healthy plants through stem cutting.

- $\quad$ Among different media, it is recommended that compost and FYM should be used for better production of fig cuttings.

- It is recommended that cuttings of fig should be collected on January $15^{\text {th }}$ for better survival and success.

\section{CONFLICTS OF INTEREST}

None.

\section{FUNDING SOURCE}

None.

\section{ACKNOWLEDGEMENTS}

I deeply appreciate the efforts of all faculty members of the Department of Horticulture, especially to my supervisor Dr.Shah Masud Khan for his time and valuable suggestions for the completion of this paper.

\section{LIST OF ABBREVIATIONS}

ANOVA Analysis of Variance

CRD

Complete Randomized Design

FYM

Farm Yard Manure

LSD

Least Significant Difference

\section{REFERENCES}

1. Mawa S, Husain K, Jantan I. Ficus carica L.(Moraceae): Phytochemistry, traditional uses and biological activities. Evid-Based Compl Alt Med. 2013; 1-8.

2. Khadivi A, Anjam R, Anjam K. Morphological and pomological characterization of edible fig (Ficus carica L.) to select the superior trees. Sci Hortic. 2018; 238:66-74.

3. Flaishman MA, Rodov V, Stover E. The fig: Botany, horticulture, and breeding. Hortic Rev. 2008; 34:1138.

4. Lim TK. Curcuma aeruginosa in edible medicinal and non-medicinal plants. Springer Chem. 2016; 233-40.

5. Anonymous. The medicinal fruit of the Quran. Retrieved from Houzz. 2017. http://Forums.Gardenweb.Com/Discussions/1884160/ Fig.

6. Bisi RB, Locatelli G, Barbosa CMDA, Pio R, Balbi RV. Rooting of stem segments from fig tree cultivars. Acta Sci Agron. 2016; 38(3):379-85.

7. Veberic R, Colaric M, Stampar F. Phenolic acids and flavonoids of fig fruit (Ficus carica $L$.) in the northern Mediterranean region. Food Chem. 2008; 106(1):1537.

8. Solomon A, Golubowicz S, Yablowicz Z, Grossman S, Bergman M, Gottlieb HE, Altman A, Kerem Z, Flaishman M.A. Antioxidant activities and anthocyanin content of fresh fruits of common fig (Ficus carica L.). J Agr Food Chem. 2006; 54(20):7717-23.

9. Jasmine R, Manikandan K, Niveditha B, Thirupathi K, Manikandan G. Evaluation the efficiency of Ficus carica fruits against a few drug resistant bacterial pathogens. Int J Pharm. 2014; 3(2):1394-400.

10. Antunes LEC, Chalfun NNJ, Pasqual M, Dutra LF and Cavalcante-Alves JM, May. Factors affecting on rooting of figs (Ficus Carica L.) cuttings. In II Inter Symp Fig. 2001; 605:141-6.

11. Aljane F. Spread and conservation of fig cultivars (Ficus carica L.) in Tunisia. Algerian J Arid Zones. 2006; 5:29-37.

12. Polat AA, Caliskan O. Effect of Indole butyric acid (IBA) on the rooting cutting in various pomegranate genotypes. Acta Hortic (ISHS) 2009; 818:187-92.

13. Ansari K. Effects of different collecting time and different medium on rooting of pomegranate" Malas 
torsh cv." cuttings. Envir Pharm Life Sci. 2013; 2(12):164-8.

14. Gomez KA, Gomez AA. Statistical procedures for agricultural research (2 ed.). John Wiley and Sons, New York. 1984; 680p.

15. Ozenc DB, Ozenc N, The effect of hazelnut husk compost and some organic and inorganic media on root growth of kiwifruit (Actinidia deliciosa). J Agron. 2007; 6(1):113-9.

16. Pirlak L. Effects of different cutting times and IBA doses on the rooting rate of hardwood cuttings of cornelian cherry (Cornus mas L.). Anadolu. 2000; 10(1):122-34.

17. Hussain I, Samad A, Naeem N, Ziaullah RH, Shah K, Zeb S, and Jan A, Vegetative Propagation of Fig 'Sawari' and 'Tarnab Inzar' Through Stem Cuttings. J Hortic Sci. 2018; 1(1):17-20.

18. Khan MS, Khan RU, and Waseem K. Effect of some auxins on growth of damask rose cuttings in different growing media. J Agric Soc Sci. 2006. 2(1):13-16.

19. Jamil MK, Rahman MM, Hossain MM, Hossain MT, Karim AS. Effect of potting media on growth, flowering and bulb production of Hippeastrum (Hippeastrum hybridum Hort.). Int J Appl Sci Biotechnol. 2016; 4(3):259-71.

20. Hartmann HT, Kester DE, Davies FT, Geneve RL. Plants Propagation: Principles and practices. Prentice Hall of India Private Ltd., New Delhi. $6^{\text {th }}$ ed. 1997.

21. Aljane $F$, Nahdi $S$. Propagation of some local fig (Ficus carica L.) cultivars by hardwood cuttings under the field conditions in Tunisia. Int Sch Res Notices. 2014: 1-5.

22. Alikhani L, Ansari K, Jamnejad M, Tabatabaie $Z$. The effect of different mediums and cuttings on growth and rooting of pomegranate cuttings. Iran J Plant Physiol. 2011; 1(3):199-203. 